\title{
The International Search of Persons Committed a Terrorist Act
}

\author{
Matchanov Alimjan Atabaevich \\ Head of the Department of Theory and Practice of Human Rights of the MIA \\ Academy of the Republic of Uzbekistan, Tashkent, Cand.Sc., \\ Associate Professor
}

\begin{abstract}
The article addresses on the issues related to the need to improve the search for terrorists and extremists, shows the main directions of the search activity of law enforcement agencies, examines the specifics of the criminal procedure, criminalistic support, operational tracking and international legal regulation of the search for hiding terrorists and extremists.
\end{abstract}

At the same time, the article emphasizes that the knowledge of the bases of cooperation and coordinated actions of law enforcement agencies, international organizations in the implementation of the search is a necessary condition for the successful search of hiding terrorists.

According to the author, it is necessary to know the features of the criminal procedure order, criminalistic tactics of international search of persons committed a terrorist act.

Keywords: terrorist act, terrorism, law enforcement, criminal, international crime, attack, international cooperation

The act of terrorism is considered as the international crime in the following cases: a) if the criminal and the victims are nationals of one country or different countries, but the crime has been committed outside; b) if the attack was committed against persons under international protection; c) the attack setup is at one country and it is committed in another country; d) if terrorist act is committed at one country, but a terrorist is hiding in another country, and the point on his extradition is raised.

Acts of international terrorism involve senseless loss of life, disrupt the normal diplomatic activities of states and their representatives and impede the implementation of international contacts, meetings, and transport links between the countries. This act is used as an instrument of political struggle at the most reactionary surrounding, parties and criminal organizations. There can be international, national and state terrorism.

If we address to the origin and the history of formation of international concerted actions against international terrorism, these actions have been started in the 30 s of the last century. For example, in 1934 year the following definition of terrorism was interpreted at the Conference for the Unification of Criminal Law in Madrid: "the application of any means to spread terror among the civilian population in order to destruct any social organization". 
In 1937 year more than 20 countries have signed the Convention on the Prevention and Punishment of Terrorism. Here the term terrorism means "criminal acts against the state, which pursue the purpose to cause threats in certain people or among the population" (article 1). These included acts against life, health and freedom of heads of states, persons enjoying prerogatives of heads of state, their hereditary or designated successors; spouses of these persons; persons exercising public functions, the acts committed in connection with their functions; and the destruction of or injury to public property or property of another State; the intention to achieve human deaths through the creation of a common danger, the facts of production, purchase, storage, supply of weapons, explosives or other harmful compounds for committing these crimes [1].

Terrorism acts are prohibited at the time of armed conflicts according to the rules of international humanitarian law, including according to the provisions of the 1977 Additional Protocols to the Geneva Conventions on the Protection of War Victims, 1949.

Subsequently the frameworks for international cooperation in fighting against international terrorism started to be expanded. The UN Special Committee was established. It coordinates the activities of states focused on the study and eliminating the causes of terrorism and on the fight against it. Upon its initiative, the UN General Assembly has repeatedly condemned acts of international terrorism, pointed at the inadmissibility of its broad interpretation, and in 1984 it adopted a special resolution on inadmissibility of the policy of state terrorism and any states' actions aimed at destructing the socio-political system in other sovereign states.

In December 1973 the UN General Assembly adopted the Convention on the Prevention and Punishment of Crimes against Internationally Protected Persons, including diplomatic agents. According to the Article 1 Internationally Protected Persons are heads of states, head of governments during their stay in a foreign country, the minister of foreign affairs, family members who accompany these persons abroad; representative of state or other officer entitled to have a special protection; officer or agent of the international organization and family members living with them [5].

Measures to prevent the international terrorism and strengthen the fight against it are provided in decision VIII of United Nations Congress on the Prevention of Crime and the Treatment of Offenders "Measures to combat international terrorism", 1990 and the Convention on the Safety of United Nations and Associated Personnel, 1994. The Convention 
on the Marking of Plastic Explosives (EX) 1991 plays a certain role in the prevention of international terrorism acts. The States have committed to put marking on plastic explosives to detect them in case of terrorist attacks. Within three years their stocks should be destroyed, used or made unusable. Military and police stocks will be disposed within 15 years. Political units combating the international terrorism were included into final documents of the meeting of members of the Organization for Security and Cooperation in Europe (OSCE) in Helsinki, Madrid, Vienna and Paris. Three regional agreements were enacted; 1971 OAS Convention to Prevent and Punish Acts of Terrorism Taking the Form of Crimes against Persons and Related Extortion, if such acts are international; 1977 European Convention on the Suppression of Terrorism; 1987 SAARC Regional Convention On Suppression of Terrorism. The Committee of Foreign Ministers on Terrorism is working in the framework of the European Economic Community (EEC).

Despite the abundance of international legal instruments and agencies coordinating the fight against international terrorism in international law, till this day there is no universal agreement defining the concept of international terrorism, its legal nature and responsibility [2]. There is no the exhaustive list of acts of international terrorism as well.

In virtue of the analysis of international agreements, the following list of such acts can be defined: a) explosions of embassies, missions, representative offices and headquarters of international organizations; b) acts of sabotage in the streets, airports, railway stations, cultural centers, industrial buildings, places for commercial and professional activities, which are related to the destruction or damage to property and causing injury or death of people; c) the deliberate use of explosive devices built into parcels, packages, letters and other postal items; d) any act of sabotage against public buildings; e) conspiracy to commit acts of international terrorism and complicity in any form, etc. According to different sources the acts of international terrorism include: hostage, piracy, acts against the safety of civil aviation, and illegal seizure and use of nuclear material. However, due to their particular international threat, prevalence and diversity in forms of commission, to deal with them states are adopting special conventions and devote some of them to certain crimes of international concern.

Thus, the following intentional acts are considered as the international terrorism: murder, kidnapping or other attack against the person or liberty of these persons; violent 
assault against official premises or vehicle of such person, if the attack is dangerous to such person or his/her liberty; threat, attempt or complicity in such attack.

At the present time in the modern world the acts of international terrorism are committed. The persons who committed these crimes are on the wanted list. Now a scientific study of this problem is urgent. Knowledge of fundamentals of criminal investigation theory and practice represent a great importance for successful solution of problems related to the investigation of acts of international terrorism.

In this regard, the use of methods, techniques, ways of search, including the most important rules of investigative activities, will create all necessary conditions for arresting terrorists.

Successful implementation of investigative activity has significance in international area as well, because more and more crimes are transnational and are moving beyond national boundaries acquiring international dimension.

International search, by definition, represents a set of investigative, information and reference and other activities by the competent authorities of the state, which is the initiator of investigation and of foreign countries, where the activities are aimed at detection, arrest and surrender (extradition) of wanted criminals [6].

One of the main types of international search is a search for a person committed an act of terrorism and who is hiding from the law enforcement agencies. To implement successfully the international search for a person fleeing from justice, law enforcement agencies should always remember about the necessity to take preventive measures. It may be achieved due to immediate application of urgent, initial measures of the search for those who have committed an act of terrorism.

The practice of investigating authorities shows that wanted people often leave for foreign countries and stay there illegally until good days to avoid criminal liability. That is why, a long-term uncertainty relating to the place of location of such people and the absence of any effective investigation are the evidence of poor and inefficient investigative activities.

For this purpose, it is important to have knowledge of theoretical, practical and institutional fundamentals of international investigation in course of detection and investigation of acts of international terrorism. The methods, techniques, ways of the international investigation, which are specified in the regulations, including the most 
important rules of investigative activity, establish organizational and legal basis to improve the activity.

Currently, in all countries, where the legal system is developed, "there is a persistent search for the most efficient forms of detection and investigation of crimes" [3].

The system of investigative activities included into the national criminal procedural law and international agreements is applied to find the location of wanted criminals. If a person can escape beyond one state, according to universally recognized rules of international law, the provisions of various conventions, bilateral or multilateral treaties may be applied and international search for criminals may be implemented.

International search for a person committed terrorist crimes is one of the activities of law enforcement agencies and is conducted provided by a strict adherence to national criminal procedural law and international treaties and agreements.

This kind of international investigation, except for as provided by national legislation, is based on various sources of international law, including on international agreements. Consequently, when declaring the search, if the fact of leaving by a wanted accused person for abroad is be ascertained and his/her exact location is unknown, the interstate or international search will be declared.

The applicable procedure for placing a person to the above mentioned wanted list does not eliminate the possibility to send to the National Central Bureau of International Police of the country a request for individual search within their territory, if there is credible information on relationships of a wanted person in this country. Account must be taken of the fact that wanted people can stay both within the territory of the Commonwealth of Independent States (CIS), and in other foreign countries.

In terms of the scale of investigation the international search can be divided into interstate (within the CIS countries) and the international (through the Interpol). Therefore, a person, who committed a crime, can be placed both to interstate and international wanted list.

According to the international agreement of the Commonwealth of Independent States, which provides the international search to be conducted on the basis of the Treaty of CIS member states on the International Search, and which was signed in Moscow on December 10, 2010 year [4], entered into force in the Republic of Uzbekistan on 24 August, 2011.

If we refer to the experience of the United States in conducting the search for criminals fleeing from justice, we can state that there is a criminal record, which is called "criminal 
identification system" and it is very comprehensive, because all participants of the criminal process are registered, including the person, who committed a crime. These persons are registered by their fingerprints, appearance, and not only by using the description of these features, but by using the photographs and recognizing a criminal according to the method of crimes committing by him/her. Fingerprint records are conducted using 10-fingerprint identification system.

This allows to monitor continuously and accurately the occurrence of information on fingerprints of a wanted person throughout the United States, to determine the location of fingerprints, which are a "point of reference" for detection and arresting the accused person, because it is a place of possible location of the wanted person. It has a direct relevance for determining the boundaries and scope of investigation activities, and, in our opinion, in these terms the organization will increase the efficiency of criminals search.

The study of international best practices in using modern procedural and criminalistic methods for organization of investigative activities by national law enforcement agencies, their interaction with international law enforcement agencies in conducting the investigative function, shall allow to conclude that it is characterized by the following trends of development and prospects of organization of the search for persons who have committed a crime:

1) computerization of the search for criminals through the Internet or another international information network;

2) creation of international system of information exchange among various law enforcement agencies, including international organizations, on the basis of computer technologies providing the immediate transmission of information from the addressee to the consumer, including the protection of the system against unauthorized access or interception;

3) large-scale re-equipment of investigation units and investigative agencies on the basis of international agreement between governments, intergovernmental organizations with more powerful and faster, mobile technical means;

4) universal international computerization of all types of identification: habitologic, phonoscopic, fingerprint, trasological, audio and videoscopic, etc. Establishment of specific international information retrieval systems to be used for investigations by law enforcement agencies on the basis of these types of identification; 
5) the establishment, on an international scale, of the electronic cartographic system, delimiting the details and scope of investigative activities related to a person fleeing from justice, including the exact definition of his/her domicile, place of work, information on his/her family, place the possible location, residence of former accomplices, place of residence and work of close friends, and the place, where criminals can meet, provided by the availability per each territory unit of the list of wanted people related to the wanted accused person, including the degree of operational support of the area, where a wanted criminal may hide;

6) considering the possibility that a wanted person may change his/her appearance by a plastic or other type of surgery, it is necessary to introduce to the work of law enforcement officers, who carry out the search, the possibility to scan the retina of the criminal to identify the person in case of his/her charge or arrest.

Currently, there is an urgent need for adopting international agreements and legislative measures to optimize the criminal procedural law, which is governing the organization of the search for criminals, taking into account current trends in forensic science development and technological progress.

Thus, the international search for wanted persons, who committed a crime, should proceed from the optimization of work of the national law enforcement agencies and international organizations to implement systematic, effective activities. For this purpose some aspects should be taken into account, including:

- international search for wanted persons, who committed crimes in current conditions of development and intensification of international relations, is one of the most important areas of cooperation between states in the fight against crimes;

- international search is a complex investigation, information and reference and other activities by the competent authorities of the state, which is the initiator of investigation and of foreign countries, where the activities are aimed at detection, arrest and surrender (extradition) of wanted criminals;

- considerations of the national criminal procedural law, which is governing the procedure for relations with law enforcement agencies of foreign states on legal assistance in criminal matters and extradition of criminals;

- improving the organizational basis of law enforcement agencies cooperation with the Interpol NCB of the country; 
- insertion of data on internationally wanted criminals into Internet database, not only into the Interpol General Secretariat website, but into websites of national law enforcement agencies and the media.

\section{References}

1. Vashchenko Iu.V. Opyt bor'by s terrorizmom za rubezhom. [Experience in the fight against terrorism abroad]. In "Prestupnost' i zakonodatel'stvo". Moscow, 1999, P. 379.

2. Emel'ianov V.P. Terrorizm kak iavlenie i kak sostav prestupleniia.[Terrorism as a phenomenon and as a component of a crime] Khar'kov: "Pravo", 1999. P. 12.

3. Kartokhina O.A. Sledstvie: vchera, segodnia, zavtra. [Investigation: yesterday, today, tomorrow ] // Rossiiskii sledovatel'. 2005. No 1. P. 3-4.

4. Collection of International Treaties of the Republic of Uzbekistan. 2012, No 1-2.

5. International Terrorism and World Security, L., 1998. P. 14.

6. Putova I.V. Mezhdunarodnyi rozysk prestupnikov: Pravovye, organizatsionnye, operativno-takticheskie aspekty: [International search for criminals: Legal, organizational, operational-tactical aspects] avtoref. dys. ... kand. jurid. nauk. Moscow, 2001. 23 p.

\section{Translation of the Title, Abstract and References to the Author's Language}

1. Ващенко Ю.В. Опыт борьбы с терроризмом за рубежом. Преступность и законодательство. Москва. 1999. С. 379.

2. Емельянов В.П. Терроризм как явление и как состав преступления. Харьков: Право. 1999. С. 12.

3. Картохина О.А. Следствие: вчера, сегодня, завтра. Российский следователь. 2005. № 1. C. 3-4.

4. Collection of International Treaties of the Republic of Uzbekistan. 2012. No 1-2.

5. International Terrorism and World Security, L., 1998. P. 14.

6. Путова И.В. Международный розыск преступников: Правовые, организационные, оперативно-тактические аспекты: автореф. дис. ... канд. юрид. наук. Москва, 2001. 23 с. 